\title{
Potential Bacterial Contaminants in the Handles of Car Doors
}

\author{
Raad A. AL-Harmoosh¹, Ali J. Eidan², Hazim A. Al-Hadrawyㄹ, Qasim A. \\ Mohammed $^{1}$ and Ameer Q. Hamed ${ }^{1}$ \\ ${ }^{1}$ Department of Ecology, College of Science, University of Kufa, Iraq. ${ }^{2}$ Department of Basic Medical Science, \\ College of Nursing, University of Kufa, Iraq.
}

\begin{abstract}
The prevalence of bacterial presences on the handles of car doors in Al-Najaf Province was evaluated. The current study was carried out between December 2017 and March 2018. A total of 100 samples were collected and cultured for bacterial isolation. The incidence of positive specimens was as the follow; (40\%) with bacterial cultures, $(52 \%)$ with yeasts cultures and $(8 \%)$ with negative aerobic cultures. In addition, the current results involved that $(\mathbf{7 0 \% )}$ of isolates was Gram positive and $(30 \%)$ of isolates was Gram negative. The most isolated bacteria were $S$. aureus, Klebsiella sp., E. coli, Proteus sp., Salmonella sp., Bacillus sp., and Streptococcus sp. The current study was indicated high prevalence rate of bacteria on the handles of car doors in Al-Najaf Province.
\end{abstract}

Keywords: Bacterial contamination; Infection; Door Handles; Infectious diseases.

*Correspondence: raada.almusawi@uokufa.edu.iq

(Received: 09 October 2018; accepted: 07 December 2018)

Citation: Raad A. AL-Harmoosh, Ali J. Eidan, Hazim A. Al-Hadrawy, Qasim A. Mohammed and Ameer Q. Hamed, Potential Bacterial Contaminants in the Handles of Car Doors, J Pure Appl Microbiol., 2018; 12(4):2193-2198. http://dx.doi.org/10.22207/JPAM.12.4.58

(c) The Author(s) 2018. Open Access. This article is distributed under the terms of the Creative Commons Attribution 4.0 International License which permits unrestricted use, sharing, distribution, and reproduction in any medium, provided you give appropriate credit to the original author(s) and the source, provide a link to the Creative Commons license, and indicate if changes were made. 


\section{INTRODUCTION}

The Handles of car doors are one of the most important environmental places for microbial infection and disease transmissions through a direct contact on a daily basis ${ }^{1,2}$.

In previous studies, the prevalence of microbial contamination on indoor environmental places such as homes, offices and restaurants was at high level. Now, many studies indicate that the source of these microbes is the pollution of the external environmental places and its transfer to the interior in many ways, most notably through direct contact ${ }^{3,4,5}$.

There are many bacterial species on the contaminated solid surfaces, which frequently used such as handles of car and house doors. The most important of these bacterial species are belonging to genus of Staphylococcus, thus it represents one of the most important sources of infection. Naturally, Staphylococcus sp. colonize human skin and thus easy access to such places, making it a focus of microbial contamination and increased possibility of disease because of the arrival of these bacterial contaminants to places other than their natural places ${ }^{6,7,8,9}$.

In addition, several studies have indicated the possibility of transmission of diseases through a variety of tools, such as the towels, razors, children's toys, stairs, switches and other elevators ${ }^{10,11}$. Recently, nano-silver particles, are anti-microbes, and characterized by low toxic, low-cost, environmentally friendly and harmless, have been used in making of handles of car doors.

Furthermore, the handles of copper doors can kill some microorganisms such as bacteria and fungi; therefore, it is preferable to make the handles of door from copper. As a result of contact with these surfaces might be contaminated with dangerous pathogens, personal hygiene and hand washing are most important ways to avoid microbial infection ${ }^{12}$.

\section{MATERIALS AND METHODS}

\section{Sample collection}

A total of (100) samples from handles of car doors was collected using sterile swabs that were transferred to the laboratory within half an hour. All samples were diluted with saline solution. From each, $0.1 \mathrm{ml}$ has been taken for culture on some selected culture media ${ }^{13}$.

\section{Samples processing}

For the purpose of counting and diagnosing of the bacteria that cause contamination of the handles of car doors, all samples were processed according to the following steps: culture, counting of the colonies using the colony counter device, gram stain and biochemical tests.

\section{Isolation and identification}

All culture media were prepared according to instructions of the manufacture and sterilized at $121^{\circ} \mathrm{C}$ and $15 \mathrm{lb} / 2 \mathrm{~g}$ for 15 minutes $^{14}$. Biochemical tests were performed using API20 tapes according to instructions of manufacture (BioMerieux).

\section{RESULTS}

The current study showed contradictory results among collected samples that have been taken as shown in table (1). The percentage of positive bacterial culture and yeast culture were $(40 \%)$ and $(52 \%)$ respectively, while the percentage

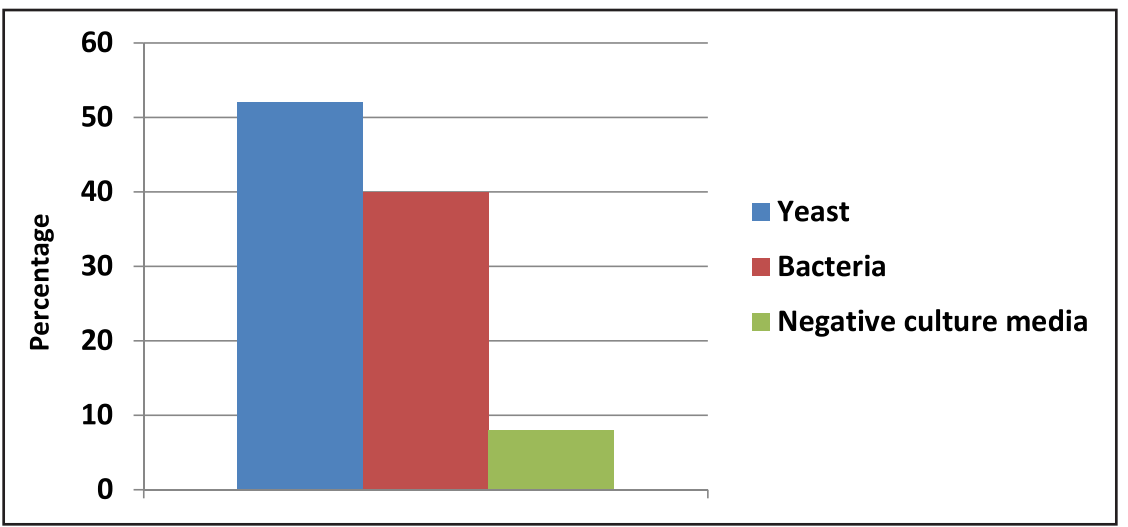

Fig. 1. Bar chart of percentage distribution for positive culture media (bacteria and yeast). 
Table 1. Counting of bacterial colonies on the contaminated handles of car doors.

\begin{tabular}{|c|c|c|c|c|c|}
\hline No. & Sample No. & Mean of Colonies & No. & Sample No. & Mean of Colonies \\
\hline 1 & S-1 & 300 & 51 & S-51 & yeast \\
\hline 2 & $\mathrm{~S}-2$ & 0 & 52 & S-52 & yeast \\
\hline 3 & S-3 & 50 & 53 & $S-53$ & yeast \\
\hline 4 & S-4 & yeast & 54 & S-54 & yeast \\
\hline 5 & S-5 & 300 & 55 & S-55 & yeast \\
\hline 6 & S-6 & yeast & 56 & S-56 & yeast \\
\hline 7 & S-7 & yeast & 57 & S-57 & yeast \\
\hline 8 & $\mathrm{~S}-8$ & 25 & 58 & S-58 & yeast \\
\hline 9 & S-9 & 15 & 59 & S-59 & yeast \\
\hline 10 & S-10 & 30 & 60 & $S-60$ & yeast \\
\hline 11 & S-11 & yeast & 61 & S-61 & yeast \\
\hline 12 & $\mathrm{~S}-12$ & yeast & 62 & S-62 & yeast \\
\hline 13 & S-13 & 150 & 63 & S-63 & yeast \\
\hline 14 & S-14 & yeast & 64 & S-64 & yeast \\
\hline 15 & S-15 & yeast & 65 & S-65 & yeast \\
\hline 16 & S-16 & 20 & 66 & S-66 & yeast \\
\hline 17 & S-17 & 0 & 67 & S-67 & yeast \\
\hline 18 & S-18 & yeast & 68 & S-68 & yeast \\
\hline 19 & S-19 & yeast & 69 & S-69 & yeast \\
\hline 20 & S-20 & 300 & 70 & S-70 & yeast \\
\hline 21 & $\mathrm{~S}-21$ & 75 & 71 & S-71 & yeast \\
\hline 22 & S-22 & 75 & 72 & S-72 & yeast \\
\hline 23 & S-23 & yeast & 73 & S-73 & yeast \\
\hline 24 & S-24 & yeast & 74 & S-74 & yeast \\
\hline 25 & S-25 & 50 & 75 & S-75 & yeast \\
\hline 26 & S-26 & 100 & 76 & S-76 & yeast \\
\hline 27 & S-27 & yeast & 77 & S-77 & yeast \\
\hline 28 & S-28 & 75 & 78 & S-78 & 0 \\
\hline 29 & S-29 & 200 & 79 & S-79 & yeast \\
\hline 30 & S-30 & 200 & 80 & S-80 & yeast \\
\hline 31 & S-31 & 200 & 81 & S-81 & yeast \\
\hline 32 & S-32 & 15 & 82 & S-82 & 0 \\
\hline 33 & S-33 & 75 & 83 & S-83 & yeast \\
\hline 34 & S-34 & 300 & 84 & S-84 & 0 \\
\hline 35 & S-35 & 300 & 85 & S-85 & yeast \\
\hline 36 & S-36 & 100 & 86 & S-86 & yeast \\
\hline 37 & S-37 & 200 & 87 & S-87 & 30 \\
\hline 38 & S-38 & 75 & 88 & S-88 & 25 \\
\hline 39 & S-39 & yeast & 89 & S-89 & 300 \\
\hline 40 & S-40 & 200 & 90 & S-90 & 300 \\
\hline 41 & S-41 & 75 & 91 & S-91 & 200 \\
\hline 42 & S-42 & 25 & 92 & S-92 & yeast \\
\hline 43 & S-43 & 200 & 93 & S-93 & yeast \\
\hline 44 & S-44 & 100 & 94 & S-94 & yeast \\
\hline 45 & S-45 & 200 & 95 & S-95 & 0 \\
\hline 46 & S-46 & 35 & 96 & S-96 & yeast \\
\hline 47 & S-47 & 75 & 97 & S-97 & 25 \\
\hline 48 & S-48 & 0 & 98 & S-98 & 0 \\
\hline 49 & S-49 & 100 & 99 & S-99 & Yeast \\
\hline 50 & S-50 & 300 & 100 & S-100 & Yeast \\
\hline
\end{tabular}

Table 1. continues... 
of no growth culture was (8\%), it seems that microbial contamination was very high in the surfaces of the handles of car doors in the present study.

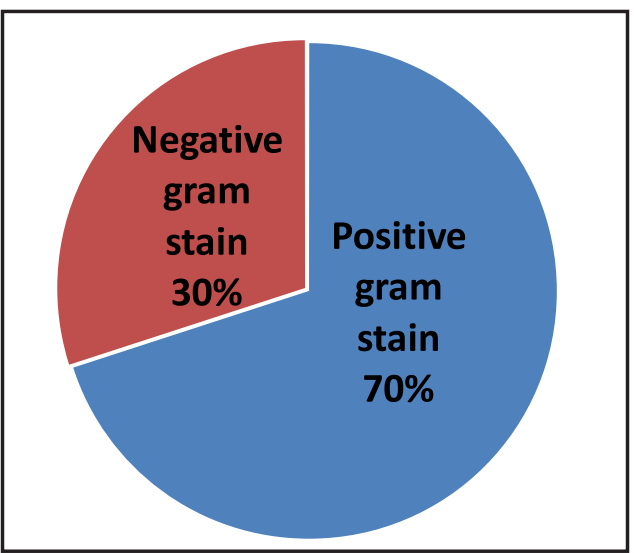

Fig. 2. Pie chart of percentage distribution for bacteria according to gram stain.

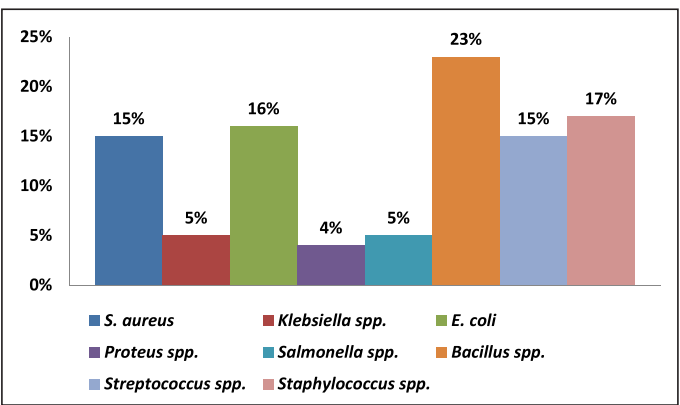

Fig. 3. Bar chart of percentage distribution of isolated bacterial species.

\section{DISCUSSION}

The handles of car, house, and office doors, are one of the most important sources of infection among users because different people repeatedly use them. The current study has shown important levels of contamination with different positive and negative gram stain bacteria. The bacterial incidence was $70 \%$ for gram positive and 30\% for gram negative (Fig.2), indicating that the majority of these bacteria are human skin's microbiota ${ }^{4}$.

In view of the current results, the levels of microbial contamination of handles of car doors was high and the percentage of positive bacterial culture and yeasts were $40 \%$ and $52 \%$ respectively, while the percentage of negative samples was (8\%), which foreshadows the possibility that these surfaces are a big source of infection.

Some isolated bacterial species (Fig.3) were attributed to human pathogenic groups such as S. aureus, Klebsiella sp., E. coli, Proteus sp, Salmonella sp., and Bacillus sp, and other were an opportunistic pathogens such as Staphylococcus $\mathrm{sp}$, , and Streptococcus sp. The current results were in consistent with results of 15,16 .

Most of the gram-negative bacterial species were Enterobacteraicea, indicating the contamination of these handles with faeces, where might cause food-borne diseases, urinary tract infections, or bronchial diseases. As well as the possibility of increased risk of skin diseases, inflammation of burns and wounds, gastroenteritis, diarrhea and other pathological injuries ${ }^{12}$.

The results of the current study were in agreement with previous studies that indicated the possibility of contamination of solids, such as handles of home doors and office doors, with opportunistic and pathogenic bacteria. Our results were closed to those found by Nworie and his colleagues $\left.{ }^{17}\right)$, and Onwubiko and Chinyeaka ${ }^{18}$ and inconsistent with another study conducted by Otter and French ${ }^{19}$.

The current study showed a significant variation in the number of isolated bacteria from various handles car doors. These results were consistent with study of Boone and Gerba ${ }^{20}$ and Nworie and his colleagues ${ }^{17}$, who demonstrated that the levels of contamination of door handles depends on the rate of use and exposure to environmental factors such as heat, drought and other environmental factors.

The majority of gram-positive bacteria (Fig. 2) were belonged to Staphylococcus and Streptococcus. In fact, the most of the endemic bacteria of human skin belong to Staphylococcus and Streptococcus. This is in agreement with previous studies indicating the role of normal flora in contaminating the most important solid surfaces ${ }^{17,21,22}$.

The presence of Bacillus bacteria with high rates in the handles of car doors in the current study (Fig.3) was mainly to the fact, that these bacterial species able to resists hard environmental conditions through the formation of internal 
spores, which have the ability to germinate and grow again, when the appropriate conditions. Dramatically, Brooks and his colleagues ${ }^{23}$ was referred to the spread of Bacillus sp, in the handles of house doors.

The present study confirmed that the current healthy procedures in the study sites were not of the required level. This may be due to the fact that most users of handles of car doors do not know the seriousness of the matter or do not know the possibility of transmission of many diseases by direct contact.

For real and effective intervention to support public health at the governmental and civil levels, it is essential highlight the importance of the subject through organization of lectures, workshops, and educational sessions.

When users are aware of the risk of transmission of many diseases from the surfaces of handles of car, homes and offices doors, this will greatly help to reduce the spread of many transitional diseases, whether bacterial or fungal and thus contribute to the promotion of public health.

It is clear that the role of personal hygiene through the importance of washing hands and the use of disinfectants and avoid eating foods without making sure to wash hands and other ways to reduce the spread of transitional diseases.

\section{REFERENCES}

1. Klepeis, NE, Nelson KE, Ott WR, Robinson J, Tsang AM, Switzer P, Behar JV, Hern SC, Engelmann S. The National Human Activity Pattern Survey (NHAPS): a resource for assessing exposure to environmental pollutants. J. Expo Anal Environ Epidemiol. 2001; 11:231-252.

2. Kembel, SW, Jones E, Kline J, Northcutt D, Stenson J, Womack AM, Bohannan BJ, Brown $G Z$, Green JL. Architectural design influences the diversity and structure of the built environment microbiome. ISME J. 2012; 6:1469-1479.

3. Pakarinen J, Hyvärinen A, Salkinoja-Salonen $M$, Laitinen S, Nevalainen A, Mäkelä MJ, Haahtela T, von Hertzen L. Predominance of Gram-positive bacteria in house dust in the low-allergy risk Russian Karelia. Environ Microbiol. 2008; 10:3317-3325.

4. Rintala H, Pitkaranta M, Toivola M, Paulin L, Nevalainen A. Diversity and seasonal dynamics of bacterial community in indoor environment. BMC Microbiol. 2008; 8:56.
5. Grice EA, Segre JA. The skin microbiome. Nat Rev Microbiol. 2011; 9:244-253.

6. Safdar N, Bradley EA. The risk of infection after nasal colonization with Staphylococcus aureus. Am J Med. 2008; 121:310-315.

7. Foster TJ. Colonization and infection of the human host by staphylococci: adhesion, survival and immune evasion. Vet Dermatol. 2009; 20:456-470.

8. Pynnonen M, Stephenson RE, Schwartz K, Hernandez M, Boles BR. Hemoglobin promotes Staphylococcus aureus nasal colonization. PLOS Pathog. 2011; 7:e1002104.

9. Payne DE, Martin NR, Parzych KR, Rickard AH, Underwood A, Boles BR. Tannic acid inhibits Staphylococcus aureus surface colonization in an IsaA-dependent manner. Infect Immun. 2013; 81:496-504.

10. Miller LG, Diep BA. Colonization, fomites, and virulence: rethinking the pathogenesis of community-associated methicillin-resistant Staphylococcus aureus infection. Clin Infect Dis. 2008; 46:752-760.

11. Kassem II. Chinks in the armor: the role of the nonclinical environment in the transmission of Staphylococcus bacteria. Am J. Infect Control. 2011; 39:539-541.

12. Wojgani, H., Kehsa, C., Cloutman-Green, E., Gray, C., Gant, V., \& Klein, N. Hospital Door Handle Design and Their Contamination with Bacteria: A Real Life Observational Study. Are We Pulling against Closed Doors? PLoS ONE, 2012; 7(10), e40171.

13. Reynolds. K. A., and Hurst C. J. Manual of Environmental Microbiology 2nd Annual Public Health Association page 9, 2005.

14. Macfaddin, J.F. Biochemical Tests for Identification of Medical Bacteria. 3rd ed. Lippincott Williams and Wilkins, USA, 2000.

15. Lynn, M. Vivian O.A and Wasa A.A. Prevalence of bacterial organism on toilet door handles. Journal of pharmacy and Biological sciences, 2013; 8:85-91.

16. Opere B.O, Ojo J.O, Omonighehin E. and Bamidele M. AntibioticSusceptibility and Plasmid Profile Analysis of Pathogenic Bacteria Isolated from Environmental Surfaces in Public Toilets. Transnational Journal of Science and Technology, 2013; 3(2): 22-30.

17. Nworie, A., Ayeni, J.A., Eze, U.A. and Azi, S.O. Bacterial contamination of door handles/ knobs in selected public conveniences in Abuja metropolis, Nigeria: a public health threat. Continental Journal of Medical Research, 2012; 6(1): $7-11$. 
18. Onwubiko, N. E. and Chinyeaka, A. H. Isolation And Identification Of Bacterial Contaminants From Door Handles In A Tertiary Institution In Umuahia, Abia State, Nigeria. Nigerian Journal of Microbiology. 2015; 29: 3139-3147.

19. Otter, J. and French, G.: Bacterial contamination in touch surfaces in the public transport system and in public areas of a hospital in London. Letters in Applied Microbiology, 2009; 49:803805.

20. Boone, S.A. and Gerba, C.P. The Prevalence of human parainfluenza virus I on indoor office formite. Food and Environmental virology, 2010; 2(1): 41-46.
21. Ducel. G., Fabry J., Nicolle L., Girard R., Perruad M., Priiss A., Sawey T. E., Thuriaux M., and Valnhems P. Prevention of Hospital Acquired Infection: A practical guide, 2nd Edition. WHO Department of Communicable Disease, Surveillance and Response: 2002; 1-9.

22. Jawetz, Melnick, and Adelberg's, Medical Microbiology $27^{\text {th }}$ ed. McGraw-Hill Education USA, 2016.

23. Brooks, G. F., Carrol, K. C, Butel, J. S., Morse, S. A., Jawetz, Melnick, Adelberg's. Medical microbiology 24th edition. New York: McGraw Hill, 2007. 